Pacific Journal of Mathematics

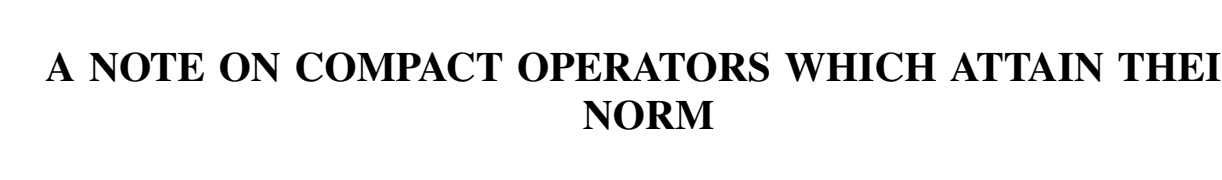




\title{
A NOTE ON COMPACT OPERATORS WHICH ATTAIN THEIR NORM
}

\author{
J. M. BAKER
}

\begin{abstract}
For Banach spaces $X$ having the unit cell of $X^{* *} w^{*}$ sequentially compact, the compact operators from $X$ into a Banach space $Y$ attain their norm in $X^{* *}$. The same holds for weakly compact operators if, in addition, $X$ has the strict Dunford-Pettis property. For Banach spaces $X$ such that the quotient space $X^{* *} / X$ is separable and $Y$ the space of absolutely summable sequences, a proper subset $P_{o}$ of the finite rank operators from $X$ into $Y$ is exhibited. The set $P_{\sigma}$ is shown to consist of operators which attain their norm and to be norm-dense in the operator space.
\end{abstract}

Throughout, $X$ and $Y$ will be Banach spaces and $\mathscr{L}(X, Y)$ the space of bounded linear operators from $X$ into $Y$. An operator $T \in \mathscr{L}(X, Y)$ attains its norm on the unit cell $S_{X^{* *}}$ of $X^{* *}$ if $\|T\|=$ $\left\|T^{* *} x^{* *}\right\|$ for some $x^{* *} \in X^{* *}$ of norm one. For general results on norm attaining operators and their density in $\mathscr{L}(X, Y)$, see [2]. A space $X$ is said to have the strict Dunford-Pettis property [4 p. 137] if for all Banach spaces $Y$ an arbitrary weakly compact operator $T \in \mathscr{L}(X, Y)$ maps weakly Cauchy sequences to strongly Cauchy sequences.

THeORem 1. Let $X$ be a Banach space with $S_{X^{* *}}$ sequentially compact in the $\sigma\left(X^{* *}, X^{*}\right)$ topology. Then

(i) if $T \in \mathscr{L}(X, Y)$ is compact, $T$ attains its norm on $S_{X^{* *}}$. Thus, every compact operator with reflexive domain $X$ attains its norm on $S_{X}$.

(ii) if $T \in \mathscr{L}(X, Y)$ is weakly compact and $X$ has the strict Dunford-Pettis property, $T$ attains its norm on $S_{X^{* *}}$. In addition, therefore, if $Y$ is reflexive, all operators attain their norms on $S_{X^{* *}}$.

Proof. There is a sequence $\left\{x_{n}\right\}$ in $S_{X}$ satisfying $\|T\|<\left\|T x_{n}\right\|+$ $1 / n$. Let $J_{x}$ be the canonical embedding of $X$ into $X^{* *}$. Since $\left\{J_{x} x_{n}\right\} \subseteq S_{X^{* *}}$ there exists a subsequence $\left\{x_{n_{j}}\right\}$ and an $x^{* *} \in S_{X^{* *}}$ such that $J_{x} x_{n_{j}} \stackrel{j}{\rightarrow} x^{* *}$ in the $\sigma\left(X^{* *}, X^{*}\right)$-topology. The sequence $\left\{x_{n_{j}}\right\}$ is weakly Cauchy in $X$, whence under either hypothesis there exists a subsequence $\left\{w_{j}\right\}$ of $\left\{x_{n_{j}}\right\}$ such that $\left\{T w_{j}\right\}$ is norm-convergent to some $y \in Y$. Since $\left\{J_{x} w_{j}\right\}$ is $\sigma\left(X^{* *}, X^{*}\right)$-convergent to $x^{* *}$ and $\left\{T w_{j}\right\}$ is weakly convergent to $y$, we have $T^{* *} x^{* *}=J_{y} y$. Thus, 


$$
\left\|T w_{j}\right\| \rightarrow\|y\|=\left\|T^{* *} x^{* *}\right\|, \quad \text { whence }\|T\|=\left\|T^{* *} x^{* *}\right\| . \quad \Delta
$$

A consequence of [9, Theorem 3] is that if $S_{X}$ is an RNP set and $\delta>0$ every $T \in \mathscr{L}(X, Y)$ may be written as $T=T_{1}+T_{2}$, where $T_{2}$ attains its norm on $S_{X}$ and $T_{1}$ is rank one (thus attaining its norm on $S_{X^{* *}}$ ) with $\left\|T_{1}\right\|<\delta$. A similar weaker result comes from [5] (proof of Theorem 1 and Remark p. 142) and Theorem 1.

CoRollary. If $X$ is a Banach space with $S_{X^{* *}} \sigma\left(X^{* *}, X^{*}\right)$ sequentially compact and $\delta>0$, every $T \in \mathscr{L}(X, Y)$ may be written as $T=T_{1}+T_{2}$, where both attain their norm on $S_{X^{* *}}$ and $T_{1}$ is compact with $\left\|T_{1}\right\|<\delta$.

Let $Y$ be a weakly sequentially complete space and $X=c$ the Banach space of convergent sequences. Every $T \in \mathscr{L}(X, Y)$ is compact [3, p. 515], and since $X^{*}$ is separable, part (i) of the theorem gives that every operator attains its norm on $S_{X^{* *}}$. Moreover, the same can occur under the hypotheses of part (ii). Such cases render the central result Theorem 1 of [5] trivial, making it desirable to find useful subsets of norm attaining operators which are dense in the operator space. Such is the purpose of the remainder of this note for the case of Banach spaces $X$ having $X^{* *} / J_{x} X$ separable and $Y=l_{1}$, the space of absolutely summable sequences. For such spaces $X, \mathscr{L}\left(X, l_{1}\right)$ consists entirely of compact operators [6, Theorem 5].

Lemma. If $X$ is a Banach space for which $X^{* *} / J_{x} X$ is separable, then $S_{X^{* *}}$ is $\sigma\left(X^{* *}, X^{*}\right)$-sequentially compact.

Proof. Let $\left\{x_{n}^{* *}\right\} \subseteq S_{X^{* *}}$. Since the $\sigma\left(X^{* *}, X^{*}\right)$-sequential closure of $X$ is $X^{* *}$ [6], for each positive integer $n$ there exists a sequence $\left\{x_{n i}\right\}_{i=1}^{\infty}$ in $S_{X}$ such that $J_{x} x_{n i} \stackrel{i}{\rightarrow} x_{n}^{* *}$ in the $\sigma\left(X^{* *}, X^{*}\right)$ topology. Let $Z$ be the closed linear span of the set $\left\{x_{n i}\right\}$ and apply the lemma in $\S 1$ of [6] to deduce that $Z^{* *}$, whence $Z^{*}$, is separable. This gives $S_{Z^{* *}}$ to be $\sigma\left(Z^{* *}, Z^{*}\right)$-sequentially compact. The remainder of the proof is straight forward using the Hahn-Banach theorem.

Let $X^{*} \otimes_{\lambda} Y$ denote the tensor product of $X^{*}$ and $Y$ equipped with the least crossnorm $\lambda$ [8]. The assignment $\left(\Sigma f_{i} \otimes y_{i}\right)(x)=$ $\Sigma f_{i}(x) y_{i}$ defines an isometric isomorphism of $X^{*} \otimes_{\lambda} Y$ onto the subspace of compact operators in $\mathscr{L}(X, Y)$ of finite rank. In the following we let $\left\{e_{i}\right\}$ be the usual unit vector basis of $l_{1}$ and put

$$
P_{\sigma}\left(X, l_{1}\right)=\left\{\sum_{i=1}^{n} f_{i} \otimes e_{i}: f_{i} \in X^{*}\right\}
$$


where $n$ is arbitrary and $f_{i}$ attains its norm on $S_{X} . P_{o}\left(X, l_{1}\right)$ is not equivalent to the tensor product of two norm dense subsets.

THeOREM 2. If $X^{* *} / J_{x} X$ is separable, $P_{o}\left(X, l_{1}\right)$ is norm dense in $\mathscr{L}\left(X, l_{1}\right)$.

Proof. Let $X^{* *} / J_{x} X$ be separable, $\varepsilon>0$ be given, and $T \in$ $\mathscr{L}\left(X, l_{1}\right)$. Since every operator in $\mathscr{L}\left(X, l_{1}\right)$ is compact and $l_{1}$ has the approximation property [7, p. 115], we have $\mathscr{L}\left(X, l_{1}\right)=X^{*} \hat{\bigotimes}_{\lambda} l_{1}$, where $\hat{\otimes}$ denotes the closure in $\mathscr{L}\left(X, l_{1}\right)$ of $X^{*} \otimes_{2} l_{1}$. Thus, there exists $T_{1} \in X^{*} \bigotimes_{\lambda} l_{1}$ such that $\left\|T-T_{1}\right\|<\varepsilon / 3$, where $T_{1}=\sum_{s=1}^{k} x_{s}^{*} \otimes$ $y_{s}$ for appropriate $x_{s}^{*} \in X^{*}$ and $y_{s}=\left(\xi_{1 s}, \xi_{2 s}, \cdots\right) \in l_{1}$. Hence, $T_{1} x=$ $\sum_{s=1}^{k} x_{s}^{*}(x) y_{s}=\left(\left[\sum_{s=1}^{k} \xi_{18} x_{s}^{*}\right](x),\left[\sum_{s=1}^{k} \xi_{2 s} x_{s}^{*}\right](x), \cdots\right)$.

The series $\sum_{j=1}^{\infty}\left\|\sum_{s=1}^{k} \xi_{j_{s}} x_{s}^{*}\right\|$ converges: if $\eta>0$ and $m, n$ are positive integers, $n>m$, there exists $N>0$ such that $n, m>N$ imply $\sum_{j=m+1}^{n}\left|\xi_{j s}\right|<\eta / k\left\|x_{s}^{*}\right\|$, for $s=1,2, \cdots, k$, because for each $s \sum_{j=1}^{\infty}\left|\xi_{j s}\right|$ converges. Thus, $\sum_{j=m+1}^{n}\left\|\sum_{s=1}^{k} \xi_{j s} x_{s}^{*}\right\| \leqq \sum_{s=1}^{k}\left\|x_{s}^{*}\right\| \sum_{j=m+1}^{n}$ $\left|\xi_{j s}\right|<\eta$.

For each $j=1,2, \cdots$, there exists a norm attaining $f_{j} \in X^{*}$ such that $\left\|f_{j}-\sum_{s=1}^{k} \xi_{j s} x_{s}^{*}\right\|<\varepsilon / 3^{j+1}[1]$, whence the series $\sum_{j=1}^{\infty}\left\|f_{j}\right\|$ converges since $\left\|f_{j}\right\|<\varepsilon \mid 3^{j+1}+\left\|\sum_{s=1}^{k} \xi_{j s} x_{s}^{*}\right\|$. We define $T_{2} x=\left(f_{1}(x)\right.$, $\left.f_{2}(x), \cdots\right)$. Since $T_{2}$ is clearly a bounded linear operator from $X$ into $l_{1}$, we note $\left\|T_{2} x-T_{1} x\right\| \leqq \sum_{j=1}^{\infty}\left\|f_{j}-\sum_{s=1}^{k} \xi_{j s} x_{s}^{*}\right\|\|x\|<\varepsilon\|x\| / 3$, whence $\left\|T_{2}-T_{1}\right\|<\varepsilon / 3$. Since there exists $N>0$ such that $\sum_{j=N+1}^{\infty}\left\|f_{j}\right\|<\varepsilon / 3$, we have $\left\|T-\sum_{j=1}^{N} f_{j} \otimes e_{j}\right\| \leqq\left\|T-T_{1}\right\|+\| T_{1}-$ $T_{2}\|+\| T_{2}-\sum_{j=1}^{N} f_{j} \otimes e_{j} \|<2 \varepsilon / 3+\sup _{S_{X}} \sum_{j=N+1}^{\infty}\left|f_{j}(x)\right|<\varepsilon$.

\section{REFERENCES}

1. E. Bishop and R. R. Phelps, A proof that every Banach space is subreflexive, Bull. Amer. Math. Soc., 67 (1961), 97-98.

2. J. Diestel and J. J. Uhl, Jr., Vector measures, Amer. Math. Soc. Survey, 15 (1977).

3. H. Dunford and J. T. Schwartz, Linear Operators I, Inter-Science Pub., N.Y., 1958.

4. A. Grothendieck, Sur les applications lineaires faiblement compactes d'espaces du type $C(K)$, Canad. J. Math., 5 (1953), 129-173.

5. J. Lindenstrauss, On operators which attain their norm, Israel J. Math., 1 (1963), 139-148.

6. R. D. McWilliams, On certain Banach spaces which are $w^{*}$-sequentially dense in their second duals, Duke J. Math., 37 (1970), 121-126.

7. H. H. Schaefer, Topological vector spaces, 2d. ed., McMillan, N. Y., 1967.

8. R. Shatten, A theory of cross spaces, Annals of Math. Studies, 26 (1950).

9. Charles Stegall, Optimization of functions on certain subsets of Banach spaces, Math. Annalen, 236 (1978), 171-176.

Received April 4, 1978.

Western Carolina University

CullowheE, NC 28723 



\section{PACIFIC JOURNAL OF MATHEMATICS}

\section{EDITORS}

Donald BABBITT (Managing Editor)

University of California

Los Angeles, CA 90024

HUGo RossI

University of Utah

Salt Lake City, UT 84112

C. C. MOORE and ANDREW OGG

University of California

Berkeley, CA 94720

\section{J. DuGUNDJI}

Department of Mathematics

University of Southern California

Los Angeles, CA 90007

R. FINN and J. Milgram

Stanford University

Stanford, CA 94305

ASSOCIATE EDITORS
E. F. BECKENBACH
B. H. NeumanN
F. WOLF
K. YoSHIDA

\section{SUPPORTING INSTITUTIONS}

\author{
UNIVERSITY OF BRITISH COLUMBIA \\ CALIFORNIA INSTITUTE OF TECHNOLOGY \\ UNIVERSITY OF CALIFORNIA \\ MONTANA STATE UNIVERSITY \\ UNIVERSITY OF NEVADA, RENO \\ NEW MEXICO STATE UNIVERSITY \\ OREGON STATE UNIVERSITY \\ UNIVERSITY OF OREGON
}

\author{
UNIVERSITY OF SOUTHERN CALIFORNIA \\ STANFORD UNIVERSITY \\ UNIVERSITY OF HAWAII \\ UNIVERSITY OF TOKYO \\ UNIVERSITY OF UTAH \\ WASHINGTON STATE UNIVERSITY \\ UNIVERSITY OF WASHINGTON
}

The Supporting Institutions listed above contribute to the cost of publication of this Journal, but they are not owners or publishers and have no responsibility for its content or policies.

Mathematical papers intended for publication in the Pacific Journal of Mathematics should be in typed form or offset-reproduced, (not dittoed), double spaced with large margins. Please do not use built up fractions in the text of the manuscript. However, you may use them in the displayed equations. Underline Greek letters in red, German in green, and script in blue. The first paragraph or two must be capable of being used separately as a synopsis of the entire paper. Please propose a heading for the odd numbered pages of less than 35 characters. Manuscripts, in triplicate, may be sent to any one of the editors. Please classify according to the scheme of Math. Reviews, Index to Vol. 39. Supply name and address of author to whom proofs should be sent. All other communications should be addressed to the managing editor, or Elaine Barth, University of California, Los Angeles, California, 90024.

50 reprints to each author are provided free for each article, only if page charges have been substantially paid. Additional copies may be obtained at cost in multiples of 50 .

The Pacific Journal of Mathematics is issued monthly as of January 1966. Regular subscription rate: $\$ 84.00$ a year (6 Vols., 12 issues). Special rate: $\$ 42.00$ a year to individual members of supporting institutions.

Subscriptions, orders for numbers issued in the last three calendar years, and changes of address should be sent to Pacific Journal of Mathematics, P.O. Box 969, Carmel Valley, CA 93924, U.S.A. Older back numbers obtainable from Kraus Periodicals Co., Route 100, Millwood, NY 10546.

PUBLISHED BY PACIFIC JOURNAL OF MATHEMATICS, A NON-PROFIT CORPORATION

Printed at Kokusai Bunken Insatsusha (International Academic Printing Co., Ltd.). 8-8, 3-chome, Takadanobaba, Shinjuku-ku, Tokyo 160, Japan.

Copyright (C) 1979 by Pacific Journal of Mathematics Manufactured and first issued in Japan 


\section{Pacific Journal of Mathematics}

\section{Vol. 82 , No. 2 \\ February, 1979}

Krishnaswami Alladi and Paul Erdős, On the asymptotic behavior of large prime

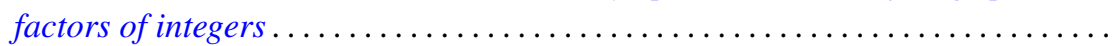

Alfred David Andrew, A remark on generalized Haar systems in $L_{p}$,

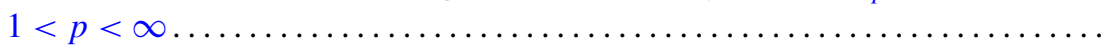

John M. Baker, A note on compact operators which attain their norm . . ........

Jonathan Borwein, Weak local supportability and applications to

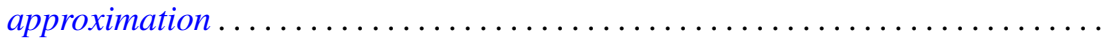

Tae Ho Choe and Young Soo Park, Wallman's type order compactification ........

Susanne Dierolf and Ulrich Schwanengel, Examples of locally compact

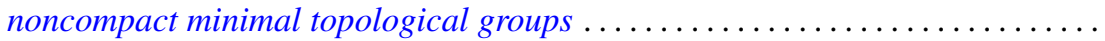

Michael Freedman, A converse to (Milnor-Kervaire theorem) $\times R$ etc. . . . . . . .

George Golightly, Graph-dense linear transformations ..................

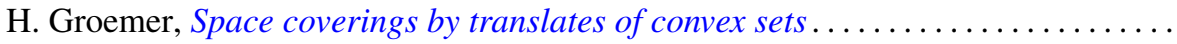

Rolf Wim Henrichs, Weak Frobenius reciprocity and compactness conditions in

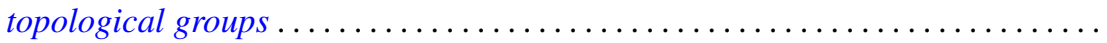

Horst Herrlich and George Edison Strecker, Semi-universal maps and universal

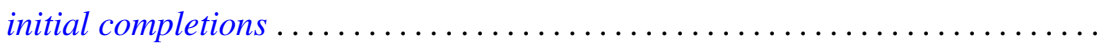

Sigmund Nyrop Hudson, On the topology and geometry of arcwise connected,

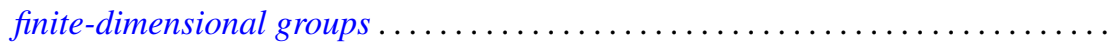

K. John and Václav E. Zizler, On extension of rotund norms. II .............

Russell Allan Johnson, Existence of a strong lifting commuting group of transformations. II.

Bjarni Jónsson and Ivan Rival, Lattice varieties covering the smallest nonmodular variety

Grigori Abramovich Kolesnik, On the order of Dirichlet L-functions .

Robert Allen Liebler and Jay Edward Yellen, In search of nonsolvable groups of

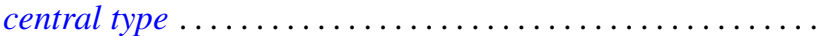

Wilfrido Martínez T. and Adalberto Garcia-Maynez Cervantes, Unicoherent plane Peano sets are $\sigma$-unicoherent ...

M. A. McKiernan, General Pexider equations. I. Existence of injective

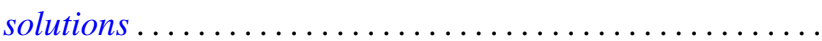

M. A. McKiernan, General Pexider equations. II. An application of the theory of webs.

Jan K. Pachl, Measures as functionals on uniformly continuous functions . .

Lee Albert Rubel, Convolution cut-down in some radical convolution algebras ...

Peter John Slater and William Yslas Vélez, Permutations of the positive integers

with restrictions on the sequence of differences. II . . .

Raymond Earl Smithson, A common fixed point theorem for nested spaces ....

Indulata Sukla, Generalization of a theorem of McFadden .... . . .

Jun-ichi Tanaka, A certain class of total variation measures of analytic measures.

Kalathoor Varadarajan, Modules with supplements .............. 